\title{
A indenização por abandono afetivo como instrumento garantidor dos direitos do menor ${ }^{1}$
}

\author{
Marina Paim de Oliveira ${ }^{2}$ \\ Prof. Ms. Márcia Teshima ${ }^{3}$
}

\begin{abstract}
Resumo
0 presente estudo visa especialmente traçar considerações acerca da questão da afetividade para o direito, descrever a moderna formação familiar bem como os direitos e deveres dos entes familiares, destacando as conseqüências do desamor para o indivíduo em formação. É objeto desse estudo ainda analisar como se insere a figura do abandono moral no campo da responsabilidade civil além das funções e conseqüências da indenização. Por fim, conclui que a indenização por abandono afetivo representa importante instrumento de garantia dos direitos da criança e do adolescente de forma mais coerente com os paradigmas da atualidade.
\end{abstract}

Palavras-Chave: Responsabilidade civil; Princípio da dignidade humana; Afeto como valor jurídico; Deveres dos pais; Direito de convivência.

\section{Introdução}

Recentemente começaram a ser submetidas à jurisdição brasileira demandas objetivando indenizações a favor de filhos que possam ter sofrido danos morais em razão da falta de afeto perpetrada pelos pais. Essa realidade evidencia que o homem passou a exigir mais do que os ordenamentos jurídicos até então possibilitavam.

Muito provavelmente o surgimento da figura do abandono afetivo está relacionado com a valorização do afeto na ciência jurídica, especialmente no campo do Direito de Família.

O direito familiarista passou de uma era conservadora e repleta de deveres a um cenário no qual a preocupação com os direitos inerentes a cada ser humano assume papel fundamental entre as pessoas.

Essas transformações de valores ficam evidentes na Constituição Federal de 1988 (CF), que, além de destinar grande importância aos chamados direitos fundamentais,

\footnotetext{
${ }^{1}$ Este ensaio teve por referência Trabalho de Conclusão de Curso apresentado ao Curso de Direito da Universidade Estadual de Londrina, de autoria da primeira sob a orientação da segunda.

2 Acadêmica do 5o ano matutino do curso de Direito da Universidade Estadual de Londrina.

${ }^{3}$ Mestre em Direito Negocial pela Universidade Estadual de Londrina.
} 
consagrou em seu artigo (art.) 1ํ, inciso (inc.) III, o princípio da dignidade da pessoa humana como um dos fundamentos da República.

Nessa esteira, ainda se encarregou a Carta M agna de reconhecer e resguardar o que já se consolidava na jurisprudência: o direito à reparação do dano moral, umbilicalmente ligado à dignidade da pessoa humana, que se mostra como verdadeiro instrumento de proteção dos direitos da personalidade.

Pelo exposto, antes de iniciar qualquer estudo sobre o abandono moral em si, resta estabelecer qual valor deve ser conferido ao afeto dentro do ordenamento jurídico. Isso porque uma vez considerado como um direito de qualquer ser humano e ao mesmo tempo um dever dos pais em relação aos filhos, trata-se de bem jurídico cuja lesão é capaz de ensejar indenização.

\section{Família, afeto e direito}

\section{A moderna formação familiar}

Diante das significativas mudanças e transformações por que passou a organização familiar, o conceito tradicional de família, como instituição jurídica formalizada basicamente pelo casamento, tornou-se incompatível com a dinâmica das relações sociais contemporâneas, que trouxe novas expectativas sociais e novas possibilidades para o direito de família.

A entidade familiar anteriormente estruturada no casamento, na hierarquia, no chefe de família, na redução do papel da mulher, nos filhos legítimos, nas funções de procriação e na unidade econômica e religiosa, está hoje centrada no afeto entre as pessoas, seja fundada do casamento, na união estável, na monoparentalidade, na consangüinidade, na adoção ou mesmo naquelas uniões ainda não reconhecidas pelo Direito como as homossexuais e as anaparentais.

Andréa Aldrovandi e Rafael Lazzaroto Simioni, em artigo publicado na Revista Brasileira de Direito de Família, acrescentam que:

A substituição dos operadores biológicos e religiosos das organizações familiares por operadores afetivos (equivalentes funcionais) também pode ser observada como um processo social irreversível de secularização (laicização) do direito. [...] Na sociedade contemporânea, só a afetividade é que dá sentido à família como forma 
de organização diferente de outros tipos de organização e isso é o que autoproduz a sua própria identidade como propriedade emergente, senérgica, autopoiética, enfim, como unidade de diferenças, como uma identidade múltipla (2006, p. 12).

As relações de família modificaram-se substancialmente, passaram, na verdade, por um processo de reconstrução, em que a preocupação com os direitos de cada indivíduo assumiu papel fundamental. A família deixou de ter a característica de desigualdade entre seus membros para ser concebida com base nos princípios da liberdade e da igualdade.

Veja-se que a alteração na estrutura do modelo familiar relativizou a função que cada membro da família ocupa, pois não se prende mais, naquela disposição tradicional: pai, mãe e filho; ao primeiro cabendo o comando e a gestão do lar. Outras e variadas configurações familiares rompem as correntes da família matrimonializada, que já não corresponde mais às relações de fato em que se envolvem as pessoas no tempo contemporâneo (ANGELUCl, 2006).

0 desafio dos dias atuais tem sido encontrar aquilo que identifica e diferencia uma relação qualquer de pessoas de uma relação familiar. Sobre essa questão, a melhor doutrina é uníssona em afirmar que esse referencial identificador das estruturas interpessoais que permite nomeá-las como família é definitivamente o fator afetivo.

Ou seja, é o envolvimento emocional que leva a subtrair um relacionamento do âmbito do direito obrigacional para inseri-lo no direito das famílias, que tem como elemento estruturante 0 sentimento de amor que funde as almas e confunde patrimônios, que gera responsabilidades e comprometimentos mútuos (VILLELA, apud DIAS, 2005, p. 40).

Ao lado das intensas transformações do modelo familiar, também os direitos da personalidade ganharam força nas últimas décadas, permitindo a escalada dos valores existenciais sobre os materiais. Nesse sentido, a contribuição de Paulo Luiz Lôbo Netto:

[...] a história do direito elucida uma grande preocupação com o destino do patrimônio, além de uma inquietude visceral com a consangüinidade legítima. Porém, o que se sabe é que o amor não é fruto da biologia, derivando-se os laços de afeto e de solidariedade da convivência familiar e que, além dos direitos reais, temos os direitos da personalidade. 0 desafio que se coloca aos juristas, no que refere aos direitos de família, é a capacidade de ver as pessoas em toda a sua dimensão ontológica, como sujeitos de direitos e não somente como titulares de bens patrimoniais. A restauração da primazia da pessoa humana, nas relações civis, é a condição primeira de adequação do direito à realidade social (apud SCHUN, 2006, p. 73). 
A ordem constitucional de 1888 foi a que primeiro trouxe inovações significativas para que se iniciassem avanços na atual situação jurídica familiar, instituindo a união estável, o princípio da igualdade jurídica entre os cônjuges e o reconhecimento civil do casamento religioso, além de um rol extenso de direitos à criança e ao adolescente, proporcionando ao mundo jurídico uma verdadeira transformação de idéias até então rechaçadas pelo ordenamento.

Não cabe mais ao Direito decidir de que forma a família deve ser constituída ou quais serão as motivações juridicamente relevantes à sua constituição; seu âmbito de atuação deve limitar-se ao controle da observação dos princípios orientadores. Por essa razão percebe-se uma intervenção cada vez maior do Estado na tentativa de preservar esses princípios, principalmente nas relações paterno-filiais em que prevalece a doutrina da proteção integral da criança e do adolescente.

\section{A dignidade da pessoa humana}

Em seu art. 1o, inc. III, a CF consolidou o princípio da dignidade da pessoa humana como um dos fundamentos da República, de modo a torná-lo, no dizer de Gustavo Tepedino, "uma verdadeira cláusula geral de tutela e promoção da pessoa humana" (TEPEDINO apud OLTRAM ARI, Fernanda; OLTRAM ARI, Vitor Hugo, 2002, p. 53).

Ou seja, o intérprete das normas deverá além de utilizá-la como diretriz em busca da melhor solução dos conflitos, assegurá-la como primeiro direito do ser humano.

0 princípio da dignidade da pessoa humana deve ser visto como o fundamento de proteção do ser humano e concebido, nas relações familiares, como estruturante e conformador de todos os demais princípios.

Sob a ótica do superprincípio da dignidade da pessoa humana devem ser analisados todos os dispositivos constitucionais e infraconstitucionais, especialmente no tocante às relações familiares. Uma vez escolhida a dignidade como princípio norteador do sistema, coloca-se a pessoa como principal fim de proteção do Estado e o desenvolvimento de sua personalidade como objetivo inquestionável, vinculando o ordenamento como um todo.

Daí se dizer que a dignidade da pessoa humana é fundamento jurídico suficiente para embasar decisões judiciais que garantam indenizações civis às vítimas de abandono moral. 0 dano moral deve ser visto como meio de resguardo da dignidade do menor. 
Lizete Peixoto Xavier Schuh em publicação sobre a responsabilidade civil por abandono afetivo esclarece:

Nas relações de família, a prática de atos ilícitos poderá gerar danos materiais e morais, sendo estes últimos os que atinam os direitos da personalidade da vítima. 0 abandono material não gera nenhuma dúvida acerca das previsões legais que exigem o seu cumprimento. 0 abando moral, por sua vez, demonstra, no mínimo, um desrespeito aos direitos da personalidade, o que impõe aos lesados, em obediência ao princípio da dignidade da pessoa humana, 0 direito à busca da reparação pelos danos sofridos (2006, p. 62).

A responsabilidade civil é o instrumento constitucionalmente escolhido como meio de garantia dos direitos da personalidade e ao mesmo tempo como forma de compensação pela ofensa a qualquer desses direitos.

O amor como elemento indispensável à dignidade humana

Para a melhor doutrina, são tidos como direitos da personalidade todos os direitos subjetivos que não tenham objeto econômico e sejam inatos e essenciais à realização da pessoa. 0 direito à integridade psíquica, por sua vez, pode ser considerado como o mais fundamental entre todos esses direitos, já que implica, em última análise, no próprio direito a ter uma personalidade.

0 dano causado pelo abandono afetivo é, antes de tudo, um dano culposamente causado à personalidade do indivíduo. Macula o ser humano enquanto pessoa, dotada de personalidade, que, certamente, existe e manifesta-se por meio do grupo familiar, responsável que é por incutir na criança o sentimento de responsabilidade social, por meio do cumprimento das prescrições, de forma a que ela possa, no futuro, assumir a sua plena capacidade de forma juridicamente aceita e socialmente aprovada. Trata-se de um direito da personalidade, portanto. (HIRONAKA, 2006).

Oportuno o conceito de personalidade estampado pela psicanalista Giselle Câmara Groeninga:

Em psicanálise, o termo personalidade tem um sentido dinâmico, referindo-se ao desenvolvimento do ser e do vir-a-ser, bem como a forma como o indivíduo se mostra e é percebido pelos outros. A personalidade se constrói pela combinação de aspectos herdados e constitucionais, com experiências marcantes da vida infantil e da vida adulta, que darão sentido de continuidade ao ser (2006, p. 655). 
0 amor representa elemento indispensável para a formação da pessoa enquanto ser dotado de dignidade. Para se alcançar o pleno desenvolvimento, com início na infância, essa fase da vida deve ser protegida e amparada, no intuito de permitir a conquista da pessoa como fim em si mesma e como ser independente.

A psicologia e a psicanálise apontam a importância dos vínculos afetivos para a formação da personalidade, à medida que é por meio das identificações que a criança faz com seus pais, ou substitutos, que se desenvolve sua personalidade.

A identificação é o 'processo psicológico pelo qual um indivíduo assimila um aspecto, uma propriedade, um atributo do outro e se transforma, total ou parcialmente, segundo o modelo dessa pessoa. A personalidade constitui-se e diferencia-se por uma série de identificações'. É na família que a criança faz a passagem do narcisismo para o altruísmo. Freud, em sua obra Psicologia de Grupo e análise do ego, nos brinda com a seguinte passagem: ' 0 amor por si mesmo conhece só uma barreira - o amor pelos outros, amor pelos objetos... E no desenvolvimento da humanidade como um todo, assim como nos indivíduos, só o amor atua como fator civilizador no sentido de trazer uma mudança do egoísmo para o altruísmo' (FREUD apud GROENINGA, 2006, p. 652).

Para Giselle Câmara Groeninga, o amor não é uma qualidade instintiva, mas que depende da aprendizagem de formas de relacionamento que serão apreendidas por meio da convivência e dos exemplos que fazem sua inscrição no psiquismo, de forma consciente e inconsciente (2006, p. 656).

Como se vê, o amor é condição para entender o outro e a si, respeitar a dignidade e desenvolver uma personalidade saudável. Portanto, é na interação com o outro, inicialmente na família "que se desenvolvem na personalidade as qualidades eminentemente humanas do pensamento, auto-reflexão e empatia" (GROENINGA, 2006, p. 657). É também na família que se desenvolve fundamentalmente a capacidade ética e os valores morais em maior ou menor sintonia com o resto da personalidade.

0 amor é o sentimento que preenche o vazio e a angústia gerados no íntimo da pessoa que está em processo de reconhecimento próprio como ser racional. As conseqüências geradas pelo desprezo por parte do genitor ou responsável têm o condão de criar na criança diversos distúrbios, que geralmente interferem em sua personalidade.

Ameaçam a integridade psíquica a falta de modelos de identificação, a falta de afeto, 0 abandono ou mesmo a rejeição, trazendo falhas no desenvolvimento da personalidade (GROENINGA, 2006, p. 660). 
O ser humano ao longo de toda a sua vida não tem aptidão para viver isolado e carece da aprovação social para pertencer a um determinado grupo, necessita, em outras palavras, ser estimado para superar os medos e vazios que surgem a partir da tomada de consciência da própria existência. A criança, principalmente, depende do sentimento de confiança e não abandono em relação aos pais para o desenvolvimento saudável de sua personalidade.

Para a transformação do estado infantil em estado adulto, imperioso o respeito à infância, aos primeiros passos da longa jornada representada pela vida. Somente possibilitando 0 aprendizado sadio das experiências da vida, o processo de formação humana poderá atingir seu ápice final: a conquista da dignidade da pessoa e seu auto-reconhecimento como pessoa com plena dignidade (ANGELUCl, 2006).

Tendo em vista a relevância do estabelecimento efetivo de relações afetivas na esfera familiar, a prevenção e a compensação que a indenização civil oferece não podem ser descartadas diante de dificuldades práticas à sua aplicação, conforme pontuado em capítulo posterior.

A proteção do interesse do menor

Até a atual ordem constitucional, a criança e o adolescente eram sujeitos de apenas alguns direitos. A partir de 1988, além do fim da desigualdade entre os filhos, foi consagrado o princípio da dignidade da pessoa humana, que, dentre outras mudanças, tornou as crianças e os adolescentes verdadeiros sujeitos de direitos, os quais devem ser garantidos não só pela família, como pela sociedade e pelo Estado.

Essa categoria de sujeito de direitos encontra sua expressão mais significativa na própria concepção de direitos humanos de Lefort, qual seja, "o direito a ter direitos", que surge, na dinâmica dos novos direitos, a partir do exercício de direitos já conquistados (LEFORT apud VERONESE, 2003, p. 31). Desse ponto de partida o sujeito de direitos seria 0 indivíduo apreendido do ordenamento jurídico com possibilidades de, efetivamente, ser um sujeito-cidadão.

Outra não pode ser a interpretação do art. 227 da CF, in verbis: 
Art. 227. É dever da família, da sociedade e do Estado assegurar à criança e ao adolescente, com absoluta prioridade, 0 direito à vida, à saúde, à alimentação, à educação, ao lazer, à profissionalização, à cultura, à dignidade, ao respeito, à liberdade e à convivência familiar e comunitária, além de colocá-los a salvo de toda forma de negligência, discriminação, exploração, violência, crueldade e opressão.

Tendo em vista a máxima de que o direito e a família devem evoluir juntos, buscando formas para regular e manter as relações familiares seguras e protegidas das mazelas da sociedade, digna de aplauso a iniciativa do legislador em conferir não só à família mas a toda sociedade e ao Estado, a incumbência de priorizar e garantir a efetivação, conservação e proteção dos direitos do menor.

No que tange a intervenção do Estado nas relações familiares, Maria Berenice Dias considera que o direito de família é um direito protetivo e assistencial, pois além de proteger os entes desta estrutura deve prestar-lhes a assistência necessária para 0 seu desenvolvimento harmônico e feliz (DIAS, 2005).

Como se vê, o art. 227 da CF consolida juridicamente a noção de proteção integral da criança, posteriormente adotada pelo Estatuto da Criança e do Adolescente (ECA), além de reconhecer direitos individuais de natureza civil, política, econômica, social e cultural do infante.

No Brasil, o ECA (Lei no. 8.069/90) fez questão de reafirmar o texto constitucional, além de assegurar outros direitos inerentes à personalidade infanto-juvenil, ao inserir em seu art. 19 que "toda criança ou adolescente tem direito a ser criado e educado no seio da sua família [...]" e no art. 22 que "aos pais incumbe o dever de sustento, guarda e educação dos filhos menores".

Dentre os dispositivos do ECA destaca-se o caput do art. 4을

Art. 40. É dever da família, da comunidade, da sociedade em geral e do Poder Público, assegurar, com absoluta prioridade, a efetivação dos direitos referentes à vida, à saúde, à alimentação, à educação, ao esporte, ao lazer, à profissionalização, à cultura, à dignidade, ao respeito, à liberdade e à convivência familiar e comunitária.

$[\ldots]$

O dispositivo reafirmou a obrigação moral e legal dos pais de assegurarem aos seus filhos uma vida digna. Quando um pai ou uma mãe abandona afetivamente seu filho, deixa de cumprir seus deveres legais de assegurar sua saúde, educação e convivência familiar. 
No tocante ao direito à saúde, talvez por questões culturais ou metodológicas, há certa propensão em restringi-la apenas na vertente física, olvidando da grande relevância representada pela saúde mental, psicológica. Neste aspecto, a expansão pessoal e seu auto-conhecimento está intimamente relacionado com 0 ambiente em que se encontra a criança ou adolescente, ou seja, o ambiente familiar, surgindo assim, a distinta responsabilidade do pai e da mãe, na família tradicional, ou de quem desempenhe este papel nas contemporâneas estruturas familiares, para a capacitação daquela criança ou adolescente na sua formação como pessoa humana com dignidade (ANGELUCl, 2006).

0 dever de educação, por sua vez, acontece no plano formal, voltado à escolarização; e no informal que se faz mediante atuação direta e permanente dos pais na vida dos filhos e se mostra determinante ao desenvolvimento de sua personalidade.

\begin{abstract}
É por meio dela que o pai vai passar ao filho os valores que tem como importantes na vida, transmitindo-Ihe um ideário filosófico e religioso, bem como vai promovendo o desenvolvimento de virtudes e habilidades que, depois, serão moldadas e ampliadas na educação formal. Reveste-se de significativo conteúdo afetivo e emocional, à medida que acontece espontaneamente, na convivência estabelecida com o filho, também de relevante valor no aspecto intelectual e social, refletindo, enfim na formação do cidadão como um todo e no amadurecimento e aprimoramento da personalidade, com a transmissão de noções e conceitos que se integrarão de modo relativamente estável e duradouro na personalidade do filho (COM EL, 2004, p. 103).
\end{abstract}

Enquanto isso, o direito de convivência familiar dos filhos deve ser entendido como 0 estabelecimento de uma relação com os pais que gere uma verdadeira comunidade de vida e interesses, em que haja constante troca de experiências, sentimentos e informações.

Não fosse assim, não teria sentido algum a convivência dos filhos com os pais, posto que não função com fim em si mesma, senão que se constitui em meio para alcançar o objetivo maior de assistir, criar e educar o filho, que exige estreito relacionamento para possibilitar troca de afetos, sentimentos e idéias, experiências e promover o desenvolvimento pleno e sadio do filho (COMEL, 2003, p. 111).

Na verdade, a CF de 1988 e o ECA trazem um conjunto de princípios e direitos, para garantir ao menor esse novo status, diferenciado daquele que, até o final dos anos oitenta Ihe era conferido nacional e internacionalmente. Significa que a criança e o adolescente foram, como já enfatizado, reconhecidos como plenos sujeitos de direitos, o que implica na impossibilidade se serem desconsideradas questões que afetem diretamente sua dignidade como a ausência de afeto. 
Pelo todo exposto, o princípio do melhor interesse da criança não pode ser apenas uma recomendação ética, mas também uma diretriz determinante nas relações da criança e do adolescente com seus pais, com sua família, com a sociedade e com o Estado. Para Luiz Edson Fachin, ele deve ser entendido como "critério significativo na decisão e na aplicação da lei", tutelando-se os filhos como seres prioritários (apud LÔBO NETTO, 2004).

Sobre o princípio do melhor interesse da criança e do adolescente Maria Helena Diniz escreve que:

É um princípio norteador de controle do exercício do poder familiar, da fixação do direito de guarda e de visita em caso de separação e divórcio, e da determinação da indenização por dano moral por descumprimento do dever de convivência familiar, por conter elementos voltados ao pleno desenvolvimento da personalidade, à boa formação educacional, à realização pessoal, à integridade moral, física e psíquica da prole (DINIZ, 2006, p. 803).

o princípio do melhor interesse da criança justifica que a garantia do desenvolvimento normal de sua personalidade se sobreponha inclusive à liberdade dos pais, os quais são obrigados a cumprir com os deveres advindos da paternidade de forma responsável, independentemente de sua vontade.

\section{0 pricípio da afetividade}

Não se questiona que a convivência saudável entre pais e filhos não se esgota com a manutenção dos filhos quanto a aspectos materiais, provendo-os de alimentos, educação formal e guarda. Muito mais que isso se faz necessário para o desenvolvimento normal de sua personalidade.

Segundo Rodrigo da Cunha Pereira e Cláudia Maria Silva (2006):

A transferência de valores com a inserção do filho na vida social ocorre por meio da convivência e do afeto. E o exercício da função paterna nunca poderá estar atrelado, unicamente, ao suprimento das necessidades materiais do filho. A supressão dessa função causa ao filho, especialmente na infância, prejuízos psíquicos, morais e afetivos, que, só com dificuldades e sofrimentos, poderão ser reparados no futuro.

Desde muito tempo a instituição familiar deixou de ser entendida como uma relação apenas de poder em que os pais eram responsáveis pela educação em sentido 
estrito dos filhos. Como alhures, hoje a família é compreendida como uma comunidade afetiva em que $o$ carinho, a atenção e o respeito com os filhos fazem parte importante e imprescindível desse contexto.

Diante da compreensão de que toda criança ou adolescente tem assegurado constitucionalmente 0 direito à convivência familiar e tendo em vista que 0 afeto é a base única e essencial de formação da família contemporânea, o direito do menor à afetividade torna-se a única conclusão possível a ser extraída do sistema jurídico.

Muito embora não haja referência expressa à afetividade no ordenamento jurídico, ao se efetuar uma interpretação sistemática e teleológica da CF e do ECA, sempre considerando seus princípios informadores, tem-se que:

0 afeto foi consagrado na legislação pátria como direito fundamental para garantir a dignidade de todos, embora à palavra afeto não esteja inserida no contexto da Constituição, a mesma assegurou 0 afeto como obrigação Estatal (DIAS, 2005, p. 66).

Pelo princípio da afetividade, decorrente do princípio da dignidade humana, estão os pais ou responsáveis obrigados a fornecer ao filho o afeto, uma vez que thes cabe a responsabilidade pela formação do infante, a fim de que seja ele inserido saudavelmente na sociedade.

Na visão de Paulo Luiz Lôbo Netto (2002):

0 princípio da afetividade tem fundamento constitucional; não é petição de princípio, nem fato exclusivamente sociológico ou psicológico. No que respeita aos filhos, a evolução dos valores da civilização ocidental levou à progressiva superação dos fatores de discriminação, entre eles. Projetou-se, no campo jurídicoconstitucional, a afirmação da natureza da família como grupo social fundado essencialmente nos laços de afetividade.

Com isso, é patente que o direito converteu a afetividade em princípio jurídico, que tem força normativa, impondo deveres e obrigações aos membros da família. Não se trata de questão alheia ao Direito.

Decorre o direito à afetividade, além é claro do princípio da dignidade humana, também do princípio da solidariedade social, reconhecido como objetivo fundamental da República Federativa do Brasil pelo art. 3o, inc. I, da CF, no sentido de buscar a construção de 
uma sociedade livre, justa e solidária. Por razões óbvias, esse princípio repercute nas relações familiares, e justifica, entre outros, a teoria do desamor.

Em recente artigo publicado na Revista Brasileira de Direito de Famílias e Sucessões, Paulo Luiz Lôbo Netto, ao tratar da solidariedade, leciona com maestria:

No mundo antigo, o indivíduo era concebido apenas como parte do todo social; daí ser impensável a idéia de direito subjetivo. No mundo moderno liberal, o indivíduo era o centro de emanação e destinação do direito; daí ter o direito subjetivo assumido a centralidade jurídica, a partir de sujeitos abstratamente considerados iguais. No mundo contemporâneo, busca-se o equilíbrio entre os espaços privados e públicos e a interação necessária entre os sujeitos concretos, despontando a solidariedade como elemento conformador dos direitos subjetivos.

$[\ldots]$

0 mais importante nessa viragem rumo ao princípio jurídico da solidariedade é a compreensão de que a solidariedade não é apenas dever positivo do Estado na realização das políticas públicas, mas também que importa deveres recíprocos entre as pessoas, pois, como disse Bourgeous, os homens já nascem devedores da associação humana e são obrigados uns com os outros pelo objetivo comum.

[...]

Sem a solidariedade, a subjetividade jurídica e a ordem jurídica convencional estão fadadas a constituírem mera forma de conexão de indivíduos que permanecem juntos, mas isolados (LÔBO NETTO, 2007, p. 144).

Ainda no mesmo artigo, o autor fala da conexão entre a solidariedade e a dignidade da pessoa humana, as quais considera dois hemisférios indissociáveis da organização social, política e cultural e do ordenamento jurídico. De um lado, a dignidade como valor da pessoa humana enquanto tal e de outro, a solidariedade como os deveres de cada pessoa humana com as demais (LÔBO NETTO, 2007, p. 148).

A solidariedade deve propiciar a construção dos vínculos e laços familiares de forma livre, porém pautada na responsabilidade mútua dos familiares. A responsabilidade civil pelo abandono afetivo contempla o princípio da solidariedade à medida que houve falta do cuidado necessário dos filhos.

Nas relações entre pai e filho, ponderados os interesses contrapostos, observa-se 0 conflito entre o princípio da liberdade do pai e o princípio da solidariedade familiar. No entanto, dada a peculiar condição dos filhos, e a responsabilidade dos pais na criação, educação e sustento deles, seria incabível valorizar a sua liberdade em detrimento da solidariedade familiar e da própria integridade psíquica dos filhos. 
Observando os princípios orientadores das relações de família e as modificações por eles imprimidas, o respectivo tratamento jurídico exige uma releitura em todas as dimensões, de modo que sua existência possa ser sentida nas relações concretas, que, cotidianamente, se desenvolvem, bem como naquelas que são levadas aos tribunais (ASSUM PÇÃO, 2004, p. 60).

Ressalta-se mais uma vez o papel exercido pelo Direito nas modernas formações familiares para dizer que apesar de não lhe incumbir mais estabelecer regras para sua constituição, por outro lado, ganha força a sua função fiscalizadora e garantidora dos princípios norteadores das relações de família.

\section{Responsabilidade civil pelo desamor}

A discussão em torno da indenização moral por abandono afetivo é muito polêmica e tem gerado posicionamentos antagônicos na doutrina que apenas recentemente começa a se posicionar na tentativa de delinear os primeiros contornos do instituto.

As críticas mais veementes à indenização pelo desamor trazem como argumento que 0 amor seria alheio ao Direito, de forma que impossível ao Estado, através do Poder Judiciário, valorar monetariamente 0 afeto bem como interferir na esfera familiar na tentativa de obrigar um pai ou uma mãe a amar seu filho.

No entanto, sendo a indenização por abandono afetivo, em última análise, indenização por danos morais propriamente dita, objetiva igualmente uma compensação pelos bens imateriais agredidos, ao invés da sua reparação como acontece com os bens materiais.

Desnecessário dizer que não se dá preço à vida quando se indeniza famílias que perderam entes queridos ou à honra quando se indeniza por uma ofensa sofrida, da mesma forma que não se dá preço ao amor quando se indeniza a vítima do abandono afetivo.

Por ser o abandono afetivo espécie de dano moral, essa questão apenas retorna, com nova roupagem, à velha discussão da possibilidade de indenizar o dano exclusivamente moral, matéria já superada pelo Direito.

Determinadas regras jurídicas possuem fundo ético, atuando na inibição do que atentar contra a personalidade humana, o patrimônio personalíssimo do indivíduo. Neste diapasão, comprovando o entrelaçamento entre direito e moral, temos 0 instituto da responsabilidade civil, especificamente, no concernente à reparação civil por danos morais. Dados históricos registram época em que se considerava 
inaceitável a possibilidade de se quantificar a moral; atribuir-se um preço a dor era conceituado, muitas vezes, como uma atitude imoral. As dimensões atuais certificam que, contanto que preenchidas as condições e os pressupostos mínimos, 0 dano moral é indenizável. Suas projeções alcançam o direito à intimidade, à imagem, à honra, à vida e, o mais recente objeto de questionamento, o direito à afetividade (SCHUH, 2006, p. 63).

No que toca ao argumento de que ao Direito não incumbe impor a obrigação de amar, conforme análise anterior, a legislação pátria impõe aos pais deveres que tem que ser cumpridos mesmo à margem da sua vontade, entre eles o de possibilitar o desenvolvimento digno dos filhos na célula familiar. De fato a lei não tem o condão de coagir alguém a amar outrem, mas no caso dos pais, ainda que não haja o amor, tem que haver a presença, a atenção, 0 comparecimento.

A esse respeito, o professor Álvaro Villaça Azevedo considera que:

[...] 0 descaso entre pais e filhos é algo que merece punição, é abandono moral grave, que precisa merecer severa atuação do Poder Judiciário, para que se preserve não o amor ou a obrigação de amar, o que seria impossível, mas a responsabilidade ante o descumprimento do dever de cuidar, que causa o trauma moral da rejeição e da indiferença (AVEZEDO apud MELO, 2005).

Ao tratar dos direitos da personalidade no Código Civil Brasileiro, o professor Luis Edson Fachin, oportunamente pontua que a dignidade da pessoa vincula o Estado a ter como meta permanente a proteção, promoção e realização concreta de uma vida digna para todos (FACHIN, 2006, p. 636).

Paralelamente, os filhos têm garantido o direito à convivência e ao desenvolvimento saudável que compreende além da saúde física, também a saúde psíquica. Mesmo que não se admita impor aos pais a obrigação de amar, como defende parte da doutrina, não há como ignorar a ocorrência de lesão moral ao filho que sofre a ausência materna ou paterna.

A essas grandes, instigantes e desconfortáveis questões somam-se, certamente, outras que devem ser igualmente levadas em consideração, como - as mais comuns delas - alguém está obrigado a amar ou o desamor tem preço? Certamente, são perguntas de muito simples respostas, pois é certo que não se pode obrigar ninguém ao cumprimento do direito ao afeto, mas é verdade também que, se esse direito for maculado - desde que sejam respeitados certos pressupostos essenciais - seu titular pode sofrer as conseqüências do abandono afetivo e, por isso, poderá vir a lamentar-se em juízo, desde que a ausência ou omissão paternas tenham-Ihe causado repercussões prejudiciais, ou negativas, em 
sua esfera pessoal - material e psicológica -, repercussões estas que passam a ser consideradas, hoje em dia, como juridicamente relevantes (HIRONAKA, 2006).

Ao contrário das regras exclusivamente morais, a lei deve obrigatoriamente ser obedecida, sob pena de coerção ou sanção. No caso do abandono afetivo, comportamento ilícito praticado pelos pais contra seus filhos, o instrumento legitimado como forma de sanção aos pais e ao mesmo tempo compensação aos filhos é a responsabilidade civil.

Pablo Stolze Gagliano e Rodolfo Pamplona Filho ao rebaterem os argumentos contrários à reparabilidade do dano extrapatrimonial, elencados por Zulmira Pires de Lima, assim se manifestam quanto à alegação de imoralidade de compensar uma dor com indenização:

Na nossa o pinião, soa verdadeiramente hipócrita a sexta objeção levantada contra a reparabilidade do dano moral, pois mais imoral do que compensar uma lesão com dinheiro, é, sem sombra de dúvida, deixar o lesionado sem qualquer tutela jurídica e o lesionador 'livre, leve e solto' para causar outros danos no futuro (2008, p. 73).

Significa dizer que a condenação, ainda que não propicie a reaproximação com o filho, como argumenta parte da doutrina, nesse contexto, não tem a finalidade de compelir os pais ao cumprimento de seus deveres, mas cumpre, além da função compensatória, a punitiva e a dissuasória.

O Superior Tribunal de Justiça (STJ) ao se posicionar pela primeira vez sobre o assunto lamentavelmente considerou que o problema não poderia se solucionar pela indenização, sob o argumento de que não há essa previsão legal específica, acrescentando que a possibilidade de destituição do poder familiar já cumpre com a função punitiva e dissuasória.

No entanto, em verdade, a destituição do poder familiar nos casos de abandono afetivo perde 0 caráter punitivo e constitui verdadeiro prêmio aos pais que se desincumbem do dever de convivência, além de não ter o condão ressarcir a vítima. Ademais, é de se observar que no mais das vezes, esses pais já não desempenham suas funções nem exercem de fato o poder familiar.

Além disso, em diversas situações, especialmente naquelas em que o ofensor é 0 próprio guardião do menor, a pessoa vítima de abandono somente irá recorrer ao judiciário 
quando adulta, já que depende de representação, quando não terá mais lugar falar em destituição do poder familiar.

A resistência à indenização decorrente da rejeição e do descumprimento do dever de convivência se funda também no receio de que o instituto se torne uma indústria do dano moral, à medida em que qualquer aborrecimento trivial poderia acabar se tornando fonte de enriquecimento do requerente.

No entanto, assim no abandono afetivo como em qualquer ofensa a personalidade, a indenização do dano moral somente se tornará banal caso não sejam respeitados critérios básicos de reconhecimento do direito do ofendido. 0 receio da banalização do instituto não pode se tornar óbice a essa conquista que representa um instrumento importante na busca de um Direito de Família mais coerente com a realidade.

0 risco de o abandono afetivo transformar-se em carro-chefe de uma indústria indenizatória do afeto certamente existe, mas o Poder Judiciário pode evitá-lo, desde que, a cada caso concreto, se fizer a necessária análise ética das circunstâncias envolvidas, a fim de verificar-se a efetiva presença de danos causados ao filho pelo abandono afetivo paterno, ou materno. Afinal, o perigo de banalizar-se a indenização reside em não se compreender, exatamente, na exposição concreta de cada pretensão, o verdadeiro significado da noção de abandono afetivo, o verdadeiro substrato do pedido judicial em questão. (HIRONAKA, 2007).

Diante do caráter protetivo que assumiu o Estado na atual ordem constitucional, principalmente no que tange às relações familiares e ao menor, acertado afirmar que a concessão de indenização como forma de compensação pelo abandono afetivo é imperativo de justiça e deve ser garantida pelo Poder Judiciário. Negar a indenização moral dos filhos abandonados significa torná-los titulares de direitos vazios.

\section{Funções compensatória, punitiva e dissuatória da indenização}

Além da finalidade reparadora da indenização imposta, a compensação do dano moral exerce nitidamente outras duas funções, a saber, a punitiva do ofensor e a desmotivadora social da conduta lesiva, que tem natureza preventiva.

A função compensatória carrega a finalidade básica da reparação civil. No caso do dano moral, a reposição do bem perdido não é possível, de tal sorte que se impõe o 
pagamento de indenização em importância equivalente ao valor compensatório do direito não redutível pecuniariamente.

Circunscrito ao dano, e visando apenas a sua reparação, este sentido da responsabilidade civil é o mais caracterísco e reflete-se em todos os tipos de fatos danosos que geram o dever de reparar, sejam os decorrentes de atitudes ilícitas, atividades de risco ou quaisquer outros que impliquem relação indenizatória (MARIN, 2006, p. 427).

Ao dizerem algumas palavras sobre o bom senso do julgador, Pablo Stolze Gagliano e Rodolfo Pamplona Filho preceituam que "a indenização por dano moral deve ter justamente essa função compensatória, o que implica dever sua estipulação limitar-se a padrões razoáveis, não podendo constituir numa 'premiação' ao lesado" (2008, p. 367).

Ademais, quando o abandono moral traz conseqüências para a saúde psíquica da vítima, o reconhecimento dos danos à sua integridade psíquica bem como da ofensa aos direitos da personalidade se faz fundamental para a sua reparação em termos psíquicos, isto porque para a psicanálise, tão traumático quanto o trauma em si, é o seu nãoreconhecimento.

Essencial que se opere, no direito, sob a égide da lógica da responsabilidade, 0 reconhecimento tanto dos direitos quanto de sua violação. Em oposição à necessária e legítima objetividade da responsabilidade, opera a lógica do inconsciente e da ampliação da subjetividade que pode exacerbar indevidamente tanto a vitimização quanto os sentimentos de culpa inconscientes - dos quais todos nós padecemos e aos quais não deve fazer eco 0 direito (GROENINGA, 2006, p. 661).

Como função secundária da indenização moral, está a punitiva já que a prestação imposta gera a penalização do agente pela ausência de cautela na prática de seus atos. 0 sentido punitivo da responsabilidade civil é o mais controvertido por trazer uma confusão de atribuições entre o direito privado e o público.

Esse sentido tem aplicação questionável no direito pátrio, devendo, se aplicado, ser observada conduta que não proporcione o enriquecimento sem causa da vítima e a vingança privada. Este sentido apenas pode ser aplicado a condutas ilícito-culposas, e com maior prudência em situações que envolvam atividades de risco (MARIN, 2006, p. 436). 
Pablo Stolze Gagliano e Rodolfo Pamplona Filho também vêem com cautela a utilização da indenização como forma de punição ao agressor, principalmente para evitar que qualquer punição em valor elevado, diante de conduta muito reprovável, estimule a proliferação de outras demandas.

A natureza sancionadora não pode justificar, a título de supostamente aplicar-se uma 'punição exemplar', que o acionante veja a indenização como um 'prêmio de loteria' ou 'poupança compulsória' obtida à custa do lesante (GAGLIANO; PAM PLONA FILHO, 2008, p. 367).

A persuasão gerada pela indenização não se limita ao ofensor e acaba por incidir na função dissuatória, de cunho socioeducativo, ao tornar público que condutas semelhantes não serão toleradas pelo Direito. Uma forma de garantir, pela via indireta, o equilíbrio e a segurança desejados pelo Estado.

Verifica-se, portanto, a existência de subdivisões dentro do sentido preventivo: a
primeira refere-se à prevenção específica e pontual, que visa a inibir a ação do
agente na reincidência do ato danoso. A segunda refere-se à prevenção geral, que
visa mitigar a proliferação de atitudes danosas gerando a conviç̧ão de que quem
causar dano será responsabilizado (M ARIN, 2006, p. 428).
Desse modo, a indenização por abandono afetivo, se for utilizada com parcimônia e
bom senso, sem ser transformada em verdadeiro altar de vaidades e vinganças ou
em fonte de lucro fácil, poderá converter-se em instrumento de extrema
importância para a configuração de um Direito de Família mais consentâneo com a
contemporaneidade, podendo desempenhar, inclusive, um importante papel
pedagógico no seio das relações familiares (HIRONAKA, 2007, P. 16).

O surgimento da figura do abandono afetivo representa sem dúvida alguma importante ferramenta na busca de um direito de família mais coerente com os paradigmas da sociedade atual.

\section{Conclusão}

O fundamento do dever de indenizar o abandono afetivo de um filho demanda uma reflexão pautada no princípio da dignidade da pessoa humana e no desenvolvimento sociopsicocultural adequado dos filhos.

Muito embora não haja referência expressa ao princípio da afetividade no ordenamento, diante da interpretação sistemática e teleológica da CF, do CC e do ECA, bem 
como dos seus princípios informadores, é muito claro que o legislador concebeu uma legislação voltada ao bem-estar do menor.

Conforme todo o exposto, esse bem-estar é composto tanto da assistência econômica como afetiva, de forma que impossível haver o desenvolvimento adequado da personalidade sem que ambos os elementos estejam presentes na formação da criança.

Como se viu, o afeto é atualmente o traço que identifica e diferencia uma relação de pessoas como família. Se o ordenamento garante o direito da criança à convivência familiar e ela não recebe amor dos pais, significa dizer que em última análise, o seu direito a conviver em família não se concretizou, ainda que haja a presença física desses pais.

A ausência da convivência saudável com os pais ou com aqueles que ocupam 0 lugar-pai ou lugar-mãe tem o condão de gerar dores emocionais e inseguranças no íntimo da criança que podem culminar inclusive em patologias e transtornos de personalidade.

É certo que o Direito não tem o poder de compelir um pai e uma mãe a amarem seus filhos, no entanto, à medida que confere direitos às suas crianças e deveres aos pais delas, não pode fechar os olhos para os danos sofridos pelo menor abandonado moralmente. Como alhures, ainda que não haja o amor, deve haver o comparecimento.

Os principais argumentos trazidos pela doutrina contrária à reparação civil do abandono afetivo apenas retomam com nova roupagem a discussão da possibilidade de indenizar o dano moral, há muito tempo superada pelo Direito pátrio.

A responsabilidade civil por abandono afetivo é uma prova de que o direito familiarista começa a perseguir um caminho mais adequado ao processo de repersonalização que colocou o indivíduo no centro de suas atenções. A construção jurídica do instituto atenderá às funções compensatória, punitiva e dissuatória da indenização civil, tão essenciais para a essa mudança de paradigmas.

O Poder Judiciário, por sua vez, pode evitar que o abandono moral se torne uma indústria indenizatória através da análise ética das circunstâncias envolvidas e da prudência nas decisões, a fim de verificar em cada caso a efetiva presença de danos causados ao filho. 


\section{Referências}

ALDROVANDI, Andréa; SIM IONE, Rafael Larazarotto. 0 Direito de Família no contexto de organizações socioafetivas: dinâmica, instabilidade e polifamiliaridade. Revista Brasileira de Direito de Família, Porto Alegre, v.7, p. 5-30, 2006.

ANGELUCl, Cleber Afonso. Abandono afetivo: considerações para a constituição da dignidade da pessoa humana. Âmbito Jurídico, Rio Grande, fev. 2006. Disponível em: «ttp://www.ambitojuridico.com.br/site/index.php?__link=revista_artigos_leitura\&artigo_id=930>. Acesso em: 12 jun. 2006.

ASSUM PÇÃO, Luiz Roberto de. Aspectos da Paternidade no Novo Código Civil. São Paulo: Saraiva, 2004.

BRASIL. Constituição (1988). Constituição da República Federativa do Brasil. Brasília, DF, 1988.

BRASIL. Lei no. 5.869 de 11 de janeiro de 1973. Código de Processo Civil. Braślia, DF, 1973.

BRASIL. . Lei no. 8.069 de 13 de junho de 1990. Estatuto da Criança e do Adolescente. Brasília, DF, 1990.

BRASIL. Lei 10.406 de 10 de janeiro de 2002. Código Civil. Brasília, DF, 2002.

COM EL, Denise Damo. Do Poder Familiar. São Paulo: RT, 2003.

DIAS, M aria Berenice. M anual de direito das famílias. 2. ed. Porto Alegre: Livraria do Advogado, 2005.

DINIZ, M aria Helena. Direito à convivência familiar. In: TARTUCE, Flávio; CASTILHO, Ricardo. (Org.). Direito Civil: Direito Patrimonial, Direito Existencial. São Paulo: M étodo, 2006. p. 799815.

FACHIN, Luis Edson. Direitos da Personalidade no Código Civil Brasileiro: elementos para uma análise de índole constitucional da transmissibilidade. In: TARTUCE, Flávio; CASTILHO, Ricardo. (Org.). Direito Civil: Direito Patrimonial, Direito Existencial. São Paulo: M étodo, 2006. p. 625-643.

GAGLIANO, Pablo Stolze; PAM PLONA FILHO, Rodolfo. Novo Curso de Direito Civil. 6. ed. São Paulo: Saraiva, 2008. v. 3.

GROENINGA, Giselle Câmara. Os direitos da personalidade e o direito a ter uma personalidade. In: TARTUCE, Flávio; CASTILHO, Ricardo. (Org.). Direito Civil: Direito Patrimonial, Direito Existencial. São Paulo: M étodo, 2006. p. 645-677. 
HIRONAKA, Giselda Maria Fernandes de Novaes. Pressuposto, elementos e limites do dever de indenizar por abandono afetivo. Instituto Brasileiro de Direito de Família, 2007. Disponível em: ঝttp://www.ibdfam.org.br/?artigos\&artigo=288>. Acesso em: 31 mar. 2008.

- Os contornos jurídicos da responsabilidade afetiva na relação entre pais e filhos: além da obrigação legal de caráter imaterial. Revista do Tribunal Regional Federal 3. Região, São Paulo, v. 78, 2006. Disponível em:

«ttp://www.flaviotartuce.adv.br/secoes/artigosc/Giselda_resp2.doc $>$ Acesso em: 31 maio 2008.

LÔBO NETTO, Paulo Luiz. Direito ao estado de filiação e direito à origem genética: uma distinção necessária. Jus Navigandi, Teresina, v. 8, n. 194, 16 jan. 2004. Disponível em: বhttp://jus2.uol.com.br/doutrina/texto.asp?id=4752>. Acesso em: 25 mar. 2008.

. Entidades familiares constitucionalizadas: para além do numerus clausus. Jus Navigandi, Teresina, v. 6, n. 53, jan. 2002. Disponível em:

४ttp://jus2.uol.com.br/doutrina/texto.asp?id=2552>. Acesso em: 25 mar. 2008.

. Princípio da Solidariedade Familiar. Revista Brasileira de Direito das Famílias e Sucessões, Porto Alegre, edição de lançamento, p. 144-159, 2007.

M ARIN, Rubens Leonardo. Dos sentidos da responsabilidade civil no Código Civil de 2002 e sua correlação aos tipos. In: TARTUCE, Flávio; CASTILHO, Ricardo. (Org.). Direito Civil: Direito Patrimonial, Direito Existencial. São Paulo: M étodo, 2006. p. 425-437.

M ELO, Nehemias Domingos de. Abandono moral: Fundamentos da responsabilidade civil. Jus Navigandi, Teresina, v. 9, n. 583, 10 fev. 2005. Disponível em:

४http://jus2.uol.com.br/doutrina/texto.asp?id=6247>. Acesso em: 13 jun. 2008.

M INAS GERAIS. Tribunal de Alçada do Estado de M inas Gerais. Processo 2.0000.00.4085505/000(1). Relator: Unias Silva. Órgão Julgador: 7ạ Câmara Cível. Data da Publicação: 29/04/2004. Disponível em:

४ttp://www.tjmg.gov.br/juridico/jt_/inteiro_teor.jsp?tipoTribunal $=2 \&$ comrCodigo $=0 \&$ ano $=$ $0 \&$ txt_processo $=408550 \&$ complemento $=0 \&$ sequencial $=0 \&$ palavrasConsulta $=\&$ todas $=$ danos $\% 20$ morais\&expressao =relação\%20paterno-filial \&qualquer $=$ afetividade $\&$ sem $=\&$ radical $\Rightarrow$. Acesso em: 30 maio 2008.

OLTRAM ARI, Fernanda; OLTRAM ARI, Vitor Hugo. As tutelas da personalidade e a responsabilidade civil na jurisprudência do Direito de Família. Revista Brasileira de Direito de Família, Porto Alegre, v. 13, abr./jun. 2002.

SCHUH, Lizete Peixoto Xavier. Responsabilidade Civil por Abandono Afetivo: a valoração do elo perdido. Revista Brasileira de Direito de Família, Porto Alegre, v. 35, p. 51-77, 2006.

VERONESE, Josiane Rose Petry. Os direitos da criança e do adolescente: construindo o conceito de sujeito-cidadão. In: WOLKM ER, Antônio Carlos; LEITE, José Rubens M orato Leite. 
(Org.). Os "novos direitos" no Brasil: natureza e perspectivas. São Paulo: Saraiva, 2003. p. 3150. 